\title{
PSYCHOLOGICAL DISCOURSE OF EMOTIONS IN MEDIATION
}

\author{
Katarzyna OBERDA \\ Ph.D. student, the J an Kochanowski University in Kielce, POLAND
}

DOI 10.25128/2304-1222.19.49.05

Theaim of this article is to determinetherole of emotions in mediation in both theoretical and practical terms. Thetheoretical discussion focuses on the psychol ogical discourse of emotions from interdisciplinary perspectives including psychological, sociological and linguistic theories. To determine the role of emotions in mediation, the evaluative mediation data is analysed with the application of discursive psychology as a methodological approach stipulated by Glynos et al.

K eywords: discourse analysis, discursive psychology, emotions, mediation.

Метою статті є окреслення ролі емоцій у медіаціях як з теоретичного, так і з практичного боку. Теоретична дискусія зосереджена на психологічному дискурсі емоцій у міждисциплінарній перспективі, включаючи психологічні, соціологічні та мовні теорії. Для окреслення ролі емоцій у медіації аналізуються дані з оцінними медіаціями з використанням дискурсивної психології як методологічного підходу, визначеного Glynos та ін.

Ключові слова: дискурсний аналіз, дискурсивна психологія, емоції, медіація.

Celem tego artykułu jest określenie roli emocji w mediacji zarówno pod względem teoretycznym, jak i praktycznym. Dyskusja teoretyczna koncentruje się na psychologicznym dyskursie emocji z interdyscyplinamych perspektyw, w tym teorii psychologicznych, socjologicznych i językowych. Aby określić rolę emocji w mediacji, analizowane są dane $\mathrm{z}$ wartościujących mediacji $\mathrm{z}$ zastosowaniem psychologii dyskursywnej jako podejścia metodologicznego określonego przez Glynos i in.

Słowa kluczowe: analiza dyskursu, psychologia dyskursywna, emocje, mediacja.

\section{Introduction}

Emotions occur at all stages of mediation starting with Stage 1 i.e. convening the mediation through the stages of an opening session, communication, negotiation to Stage 5 i.e. Closure The disputants enter themediation process with their emotions understood as mental states strongly associated with the disputants' nervous systems [Panksepp 1992; Panksepp 2005; Damasio 1998; Davidson, Ekman 1994]. As mental states, thedisputants' emotions occur at the stage when legal aspects of mediation are determined either for 
court mediation or extrajudicial mediation. They accompany the disputants during the opening session. The verbal and nonverbal release of the disputants' emotions is noticeable at the communication and negotiation stages. They also accompany the disputants when they reach the final stage of mediation.

Emotions associated with thoughts, feelings, experience and behavioural responses areinextricably intertwined with their disputants' mood, disposition, and motivation in all types of mediation. The relationship between emotions and motivation widely recognised in psychological studies [Shacter, et al 2012]. This relationship has an impact on the outcomes of civil mediation, business mediation, criminal mediation, employee mediation, family mediation, peer/school mediation since the well-motivated disputants ai mat resolving their dispute.

Although mediation is the key-term in this paper, the main focus concerns the psychol ogical discourse of emotions that occur in mediation. The main objective of this article is to reconstruct the disputants' emotions involved in mediation. Therefore, firstly the review of literature relates to the psychological discourse of emotions from its historical perspective. Secondly, the analytic approach to the psychol ogical discourse of emotion in mediation is presented. Thirdly, the results of the qual itative analysis rel ated to the empirical data $[1,2,3,4,5]$ are discussed to indicate the role of the disputants' emotions in mediation with the conclusions drawn.

\section{R eview of literature}

The APA psychology dictionary defines the term discourse as "areas of written, spoken and marked communication, both formal (debate) and informal (conversation). The term is most commonly used in linguistics, in which discourse analysts focus both on language study (sentences, speech acts, and lexicons) as well as on the rhetoric, meanings, and strategies underlying social interaction"[Dictionary APA].

The history of psychological discourse on emotions as part of the study of human behaviour and mental processes goes back to the various ancient civilisations in which Egyptian, Persian, Greek, Chinese and Indian phi losophers express their views on human mind and body [Okasha, 2005; Shechy, et.al. 2002]. The historical account of psychological discourse is primarily focused on the concepts and theories that form the essential content of discourse related to such psychological issues as eg. depression and 
thought disorders [Okasha, 2005], or to the theory of humours as regulating human behaviour [Sheehy, et. al, 2002].

From the historical perspective, thepsychological discourserelated to emotions has its origins in the Hippocratic Collection from the Classical period of Greece [J ouanna, 1999]. Hippocrates' theory of four temperament types is developed further by Kant (1974), who develops Hippocrates' views on temperament into the dimensions of emotionality and energetic arousal. Kant's (1974) theory on the human emotional constitution becomes the foundation for the development of all temperament and personal ity models [Thomas, Chess, 1977, Kagan, 1997].

The evolutionary theories related to the psychological discourse on emotions starts with Darwin (1872), who discusses the expressions of animal and human emotions. Following his theory of the evolution of species Darwin (1872) argues that emotions evolve through the inheritance of the inbom character and their verbal and non-verbal expressions shoul d bestudied universal ly across various cultures. Darwin's (1872) theory on emotions is further developed in the psychological discourse by evolutionary psychology [Gaulin, McBurney 2003] or the neuropsychology [Damasio, 1998; LeDoux 1996].

The psychological discourse on emotions acquired a new dimension in the last decade of the nineteenth century. J ames (1884) introduces a new theory of emotions later developed into the James-Lange theory based on the premise that emotion is the consequence rather than the cause of the bodily experiences associated with its expression [J ames, 1884, Lange 1885].

In the James-Lange theory [James, 1884, Lange 1885], a stimulus causes a physiological response and an emotion follows the response. This theory has received criticism throughout the years since its introduction [Cannon 1927; Cannon 1931; Bard 1928]. Nevertheless, Dalgleish [2004: 583] states that modern neuropsychologists and neurol ogists foll low the components of theJ ames-Lange theory in which "bodil ly feedback modulates the experience of emotion". What is more, J ames (1890) lays the foundations for the discussion of the relationship between consciousness, emotion, and habit.

Although the psychological discourse on emotions has its origins in premodern history, the term emotion dates back to "1570s, "a (social) moving, stirring, agitation," from Middle French émotion (16c.), from Old French emouvoir "stir up" (12c.), from 
Latin emovere "move out, remove, agitate," from assi milated form of ex "out" (see ex) + movere "to move" (from PIE root* meue "to push away"'). Sense of "strong feeling" is first recorded in the 1650s; extended to any feeling by 1808 [Etymology Dictionary]. Dixon (2003) states that the term emotion refers to passions and affections in academic discussions. Smith (2015) indicates that the modern concept of emotion entered the English language in the 1830s since before people experienced passions or sentiments.

Since its occurrence in the academic discussion, the term emotion has been functioning with a wide variety of definitions. Kleinginna and Kleinginna (1981) attempt to resolve the terminol ogical confusion concerning emotions and they discuss various emotion-related categories. Kleinginna and Kleinginna (1981) open their discussion with traditional categories of affect and cognition [J ames 1884, Morris, 1979], then they concentrate on physical categories corresponding to external emotional stimuli, physiological mechanisms and emotional/ expressive behaviour [J ames 1884; James 1890; James 1894], as well as the categories of disruptive or adaptive effects [Carr 1929; Peters 1970], categories of the multi-aspect nature of emotional phenomena [Lazarus 1975] and those that overlap emotion and motivation [Plutchik 1962; Plutchik 1980; Plutchik 1991]. After the discussion of various categories of emotions, Kleinginna and Kleinginna [1981: 355] propose the following definition:

"Emotion is a complex set of interactions among subjective and objective factors, mediated by neural-hormonal systems, which can (a) give rise to affective experiences such as feelings of arousal, pleasure/displeasure; (b) generate cognitive processes such as emotional ly re levant perceptual effects, appraisals, labeling processes; (c) activate widespread physiological adjustments to the arousing conditions; and (d) lead to behavior that is often, but not always, expressive, goal-directed, and adaptive".

Kleinginna and Kleinginna's (1981) definition of the term emotion emphasises its complex interactional nature of subjective and objective factors, which are mediated by neural and hormonal systems. Moreover, thefunctions of emotions areindicated as firstly they give rise to affective experience, secondly, they generate cognitive processes and thi rdly they lead to expressive goal-directed and adaptative behaviours.

To understand thenature of emotions, wefollow the Dictionary APA which defines the term emotion as "n. a complex reaction pattern, including experimental, behavioural 
and physiological elements, with which the individual tries to deal with the personally significant matter or event. The specific quality of emotions (e.g. fear, shame) depends on the special significance of the event. For example, if the meaning is associated with a threat, fear will probably arise; if the meaning involves disapproval from another person, it is likely to be a shame. Emotion usually involves feeling, but it differs from feeling overt or covert involvement in theworld". However, to understand theemotions involved in the process of mediation we concentrate also on the functions of emotions in the mediation process.

\section{M ethodology}

In this article, the applied methodological approach is that of discursivepsychology based on DiscourseAnal ysis as a tool [Glynos et al. 2009]. This methodological approach al lows for conceptual izing the phenomena of emotion communication and cognition in discursive terms. In this methodological approach, we follow Edwards' (1997) position of discursive psychology combined with three basic theoretical principles of psychol ogical discourse [Potter 2003; Potter and Edwards 2001].

The first principle states that psychological discourse is both constructive and constructive [Potter 2003; Potter and Edwards 2001]. It is constructed because it consists of language units and structures, such as words, categories, and sentences, to represent a specific version of the world. It is constructive because in the presented world it is a product of the conversation itself.

The second princi ple reveals discourseas action-oriented not only becausespeaking or writing areactions in themselves, but discourse is the basic means of social action, eg. inviting, justifying, blaming [Potter 2003; Potter and Edwards 2001].

The third principle shows that the discourse is in a specific sequential environment, because words form sentences and are understood according to the linear sequence of this,

what precedes and foll lows them [Potter 2003; Potter and Edwards 2001].

\section{Discussion of the results}


The research problem of this article refers to the role of emotions in the process of mediation, and more precisely how the disputants' emotions influence the outcome of the mediation. The nature of this research problem is interdisciplinary, subject-matter and problem - solving oriented. The combination of those research problem features show that the research problem is not only significant in the fields of psychology, sociology, law, and linguistics but also specific as it refers to the outcome of mediation in the form of dispute resolution and manageable To provide the answer to this research question, it is necessary to conduct the anal ysis of the selected recorded data foll owing the research procedure and applied methodology described above.

The research procedure in this article is based on the key concept of the research to determinetherole it plays in the process of mediation. To obtain this objectivefivemajor steps have been applied in this quantitative emotion-rel ated research process, namely

1. Statement of the research problem

2. Review of the Literature

3. Selection of Data

4. Analysis of Data

5. Discussion of research results

The basic concept of this research is the disputants' emotions invol ved in mediation. To reconstruct the role which the disputants' emotions play in mediation, it is necessary to follow the framework of the sel ected scientific methods and anal ytical tools. Oncethe research empirical data have been sel ected and analysed, the discussion of the key terms, categories, and functions follow.

The research data come from the recorded mediation sessions entitled: An Inside Look at Family Mediation [1], Resolution through Mediation [2], Victim-offender mediation [3], Considering mediation? What you need to know? [4] as well as Family Mediation in Action [5]. The texts of the recordings have been analysed in terms of content, form and context.

\section{The structural content of emotions in mediation}

Thediscourse anal ysis of the disputants' emotions in mediation $[1,2,3,4,5]$ shows that the process of mediation starts with thenegativeemotions of the disputants (Plutchik, 1980). In some mediations, negative emotions are subject to transformational emotions 
(James, 1902/1987). As a result, thenegativeemotions aretransformed into positiveones (Plutchik, 1980) in those mediations in which the dispute resolution is reached. This process of emotional transformation in mediation is visualised on the following Fig. 1.

Conflict

\begin{tabular}{|c|}
\hline \multicolumn{1}{|c|}{ Negative emotions } \\
\hline Disputant 1 \\
\hline Transforational emotions \\
\hline Disputant 1 \\
\hline Disputant 2 \\
\hline Pisputant 1 Ditive emotions \\
\hline
\end{tabular}

\section{Conflict resolution}

Fig. 1 Model of emotional transformation in mediation (source: own elaboration)

At the initial stages of mediation, negative emotions become underlying factors of conflict. The disputants are driven by anger, fear, grief, humiliation, and frustration [1, 2, $3,4,5]$. Their negative emotional energy prevents their conflict or dispute from ending with reconciliation and resolution [1]. Embraced by the power of negative emotions they enter a mediation procedure with the view to benefiting from the effective dialogue moderated by the mediator, who should be impartial to both disputants [1]. The willingness of both disputants to continue the mediation process may be a turning point in the structural layout of their emotions in mediation $[2,5]$.

\section{Stage 1 Negative emotions}

Each conflict is connected with negative emotions to which anger, contempt, disgust, jeal ousy, fear, pain, sadness, and sorrow belong $[1,2,3,4,5]$. Out of those negative emotions, some emotions such as anger, sadness, and fear areknown as primary negative emotions that are thought to be innate while other complex negative emotions such as envy and quilt seem to be the outcome of social learning.

Anger is considered to be one of the primordial emotions usually associated with fear, grief or pain. It isfrequently evoked by frustration resulting from difficulties to attain 
the goal or to preserve the feeling of safety. Whatever, the sources of anger might be, whether they are related to theactions disturbing human safety by threats, insults, injuries or restraints. The underlying reasons for anger in mediation are usually connected with betrayal, deprivation, disapproval, exploitation, humiliation, manipulation.

In the mediation process, the emotion of anger is experienced when the disputants have wronged each other $[1,2,3,4,5]$. They both feed that they have been wronged [1, $2,3,4,5]$. Another frequently experienced emotion of contempt leads the disputants to takeactions that arefull of disapproval and disrespect, eg. My breakup with Emily was a nightmare [4], which can trigger a cycle of negativity and destruction within any human relationships [2, 4]. In the family mediation, the emotions of contempt, disgust, and jealousy usually lead the disputants to withdraw, leaving the conflict unresolved or causing a breakup of the couple $[1,5]$.

In the conflict, the emotion of jeal ousy is quite complex because it is a mixture of three primary negative emotions, namely fear, anger, and sadness [1, 4, 5]. The emotion of fear in mediation usually refers to a threat of losing a relationship either experienced consciously or subconsciously. Then the emotion of anger occurs and it is directed towards the disputant which is the source of threatening the relationship [2]. And finally, the emotion of sadness embraces the disputant, who is at the prospect of losing the relationship [1, 5].

Negative emotions influence the way the disputants interact with each other $[1,2$, $4,5]$. In the case of any mediation process, the negative emotions are challenging the disputants' relationship and contribute to the unpleasant experience of both parties $[1,2$, $3,4,5]$. If the negative emotions have been lasting for a considerable period they lead to frustration, which may be the main source of aggression, when the circumstances do not hel p for the conflict resolution [1, 2, 4]. The more frustrated the disputants are, the more aggressive they are towards each other [2].

Aggression involves a set of reactions to the fulfilled or unfulfilled need or more unfulfilled needs. The aggressive disputant evokes fear in the mind and body of the another disputant [2]. As a result, the heart rateincreases, as well as breathing rate, and pupil dilation [2]. Those physiological changes make the disputant aware of potential danger 
stimulated by aggression and fear expressed verbally eg. Now stop! Please stop that Mr. Miller! Stop! I don't want her to use these words here If she uses these words I amout of this room out of this mediation [2] as a protective mechanism to keep the disputant safe fromany harm

A nother negative emotion that occurs in conflict is that of humiliation. The disputant who is humiliated feels unpleasant in front of others, e.g. children, other employees or neighbours. Humiliation is a very intenseemotion, which plays an important rolein the conflict of individual s and as well as groups [2, 4]. According to Klein (1991), humiliation is an emotion-oriented to the action and it needs a humiliator, a victim and a witness, who have less power than a humiliator.

\section{Stage 2 Transformational emotions}

At the stages of communication and negotiations, the transformational emotions occur (J ames, 1902/1987). Once the disputants real ise that negative emotions are usually the foundations of their conflict, they employ the transformational emotions to root out and understand the underlying nature of the conflict and with those transformational emotions, they can influence their communication and negotiation process to reach the settlement $[1,2,4,5]$. Those transformational emotions usual ly become a hel pful tool to reach the final resolution eg. I can change [3].

Unlike negative emotions, transformational emotions are not structured by habitual reactions to the world [J ames 1987]. These emotional reactions are not blind instinctual responses but the acquired reaction pattern that can bring the disputants from the divided state to the unified state, i.e. from the state of conflict to the state of unification, or from the state of disintegration to the state of integration $[1,2,4,5]$.

The discussion of transformational emotions in mediation may refer to James (1987) when he explains how transformational emotions function when the individuals fall in and out of love. Those transformational emotions are generated from the subconsciousness in s sudden and instantaneous manner. This is of prime importance conceming any mediation process, as the disputants exhausted with the struggle have to stop [J ames 1987: 197]. This condition of exhaustion is usually the reason why the 
disputants express their willingness for mediation to reach conflict resolution. When the boundary between the subconsciousness and consciousness relaxes the transformational emotions floods into the consciousness, and then it is possible to talk about the 'conversion' [J ames 1987] or 'transformation' from negative to positive emotions.

\section{Stage 3 Positive emotions}

Positive emotions are necessary to conduct constructive communication and negotiation to solvethe conflict. When the disputants express the willingness to find the solut tion to the conflict they initiate the communication and negotiation process to reach their objective [5]. If they fed a need for cooperation to makea resolution to their conflict they set the goals, plans, negotiation. In these activities, they use their cognitiveflexibility and they mentally explore the new situations of negotiations conducted in the constructive forms $[1,2,4,5]$.

One of the basic emotions that leads to conflict resolution is hope. This emotion can have a positive effect on the solving of the conflict because it can formulate the expectations and aspi rations for problem-solving (Staats, Stassen, 1985). The di sputants hopethat they will work out the conflict resolution to solve the conflict in a constructive manner [2, 4, 5]. They fed anticipatory happiness that they soon will have their currently experienced unhappy situation converted into acceptable solutions to both of them.

The emotion of hope generates another positive emotion, namely that of interest in meeting their needs and achieving their goals. This interest sparked by novelty to change the current conflicted situation is a necessary prerequisite for constructive communication and negotiation [1,5]. In the process of mediation, interest as an emotion causes the disputants' attention focused on the object of the conflict to be resolved. The basic function of interest is to motivate the search for knowledge to solve the conflict $[1,2,4,5]$.

\section{The form of emotions in mediation}

In the process of mediation, the disputants' emotions are communicated both verbally and nonverbally $[1,2,3,4,5]$. The verbal form of communication is usually orally transmitted although certain messages may be transmitted in the written mode in 
the process of mediation. The nonverbal communication between the disputants refers to sending and receiving wordless messages. The nonverbal form of communication includes gestures, body language, posture, tone of voice and facial expressions [1, 2, 3, $4,5]$. Those two forms of emotional communication are vital and should be both taken into account at all stages of the mediation process.

The disputants' oral communication is mainly based on spoken words arranged in the syntactic structures. In the faceto-face conversation, the disputants convey information about the subject matters as well as the state of their emotions $[1,2,3,4,5]$. Additionally in the face-to-face conversation during the process of mediation, the mediator as well as disputants listen to the arguments, read facial expressions and body language of the speaker and discover the knowledge about the speaker's emotional state eg. I understand that the fedings are running high, so I would propose that we adjourn into a private session [2], which can prevent the disputants from identifying their private or business concems.

The disputants' emotions communicated verbally are expressed by different language means, namely vocabulary, syntax and phonetics eg. I think they are crazy [2]. There are systemic ways of expressing emotions through lexemes describing emotions such as anger, di sappointment, get nervous, metaphors, comparisons including profanity and curses, eg. You'll probably get angry [5]. Emotions communicated verbally are expressed by different language means, eg. syntactic means eg. interrogative sentences eg. How is it my fault? [1] exclamatory e.g. It's a lie! [5] or repetition e.g. It's a lie!, It's an absolute lie! [5], No, no, no [2] or phonetic means through eg. a change in tone of speech, by pitch, volume, speed or clarity of speaking $[1,2,3,4,5]$.

Emotions communicated verbally are al so expressed through lexical and syntactic factors that are very important for determining the irony of expression eg. half an hour is justification in her mind to stop me seeing the children [5]. A degree of fluency of speech that indicates a disturbance of competence and responsibility under the influence of usually strong negative emotions e.g. anger or the content (content) of statements i.e. different content may occur at different stages of meditation and reflect the relationship of the disputants, in finding ways to resolve the conflict amicably. 
The nonverbal communication of emotions shows that emotions are expressed by various non-language means of expression that include not only the body language, e.g. clenched fists, pursed lips, expressing anger, but also gestures and facial expressions in total camouflage, e.g. in economic or employee negotiations, instead of clenched fists, he grabs the pen and tries to attach it [1, 2, 3, 4, 5]. Additionally, the nonverbal communication of emotions refers to the expression of emotions by various non-language means of expression such as protective barriers, eg. women use a notebook as a protective shield, i.e. they keep it on the table or in front of them [2], and personal distance manifested by distance from the other party $[2,4,5]$.

\section{The context of emotions in mediation}

In the process of mediation, the context of emotions immediately highlights the importance of communication and negotiation as the stages of mediation. During those stages of communication and negotiation, the context of emotion is closely related to argumentation as a means to reasonably handl ethe conflict in the process of mediation [5].

During the argumentation, the disputants tackle the topics under discussion providing both theoretical insights and detailed empirical observations. The emotions associated with the expl oration of meditation as a real-life context of argumentation may contribute to the increased argumentative awareness that may improve conflict resolution or not [5].

The particular emphasis on the argumentation as a context of the disputants' emotions shoul d be taken into account by the mediator by mapping the mediation through an interdisciplinary reasoned review of existing disputants' accounts [5]. For the mediator, the study of argumentation content and form in mediation may be the main source and the sol id basis for the mediator to help the di sputants discuss reasonably. The mediator's competenceto anal ysethepsychol ogical discourse of emotions and their transformational character plays a crucial role in this relation at the levels of issue selection, evoking of cultural-contextual premises and choice of argument schemes.

Conclusions 
The use of psychological discursiveanalysis for the emotions communicated by the disputants in the process of mediation helps the mediator quickly assess the emotional state of the disputants and support them during the discharge of negative emotions to build on positive emotions. What is more, the mediator's verbalization of the di sputants' emotions at various stages of medi ation hel ps themediator performactions ai med at transforming negative emotions into positiveones, eliminating communication barriers to lead the disputants to the conflict resolution.

\section{BIBLIOGRAPHY}

Bard, P. A. A diencephalic mechanism for the expression of rage with special reference to the central nervous system "American J ournal of Psychology". 1928. 84, pp. 490-513.

Cannon, W. B. The J ames-Lange theory of emotion: A critical examination and an alternativetheory, ",American J ournal of Psychology", 1927. 39, pp. 106-124.

Cannon W. B. Against the J ames-Lange and the thalamic theories of emotions, "Psychology Revue". 1931. 38, pp. 281-295.

Carr, H. A. Psychology, a study of mental activity. New Y ork 1929.

Dalgleish, T. Theemotional brain. “NatureReviews Neuroscience” . 2004. 5 (7), pp. 58289.

Damasio, A.R. Emotion in the perspective of an integrated nervous system "Brain research. Brain research reviews". 1998. 26 (2-3), pp. 83-86.

Darwin, Ch. The Expression of the Emotions in Man and Animals. London 2009.

Davidson, R. J., Ekman P. The Nature of emotion: fundamental questions. Oxford 1994. pp. 291-93.

Dictionary APA, https://dictionary.apa.org

Dixon, T. From passions to emotions: the creation of a secular psychological category. Cambridge 2003.

Edwards, D. Discourse and cognition. London 1997.

Edwards, D., Potter, J. Discursive Psychology. London 1992.

Edwards, D., Potter, J. Discursive psychology, mental states and descriptions, in L. te Molder, J. Potter (eds.) Conversation and Cognition. Cambridge 2005, pp. 241259.

Etymology Dictionary https://www.etymonlinecom/word/emotion 
Glynos, J., Howarth, D., Norval, A., Speed, E. Discourse analysis: Varieties and Methods. "National Centre for Research Methods" 2009. 014. 1-41.

Gaulin, Steven J.C., McBurney, D. H. Evolutionary Psychology. New J ersey. 2003, pp. 121-142.

James, W. What is an Emotion. “Mind” (34), 1884, p. 188-205.

J ames, W. The Principles of Psychology, New Y ork 1890.

James, W. The Physical Basis of Emotion, "Psychological Review”, 1. 1894, pp. 516529.

J ames, W. The Varieties of Religi ous Experience, in WilliamJ ames: Writings 1902-1910, New Y ork 1987.

J ouanna, J. Hippocrates. Baltimore 1999.

Lange, C. The Emotions. Baltimore 1885.

Lazarus, R. S. A cognitively oriented psychologist looks at feedback. "American Psychologist", 1975. 30, pp. 553-561.

LeDoux, J.E. The Emotional Brain. New York 1996.

Kagan, J. In the beginning: the contribution of temperament to personality development. “Modem Psychoanal yse”. 1997, 22, pp. 145-155.

Kant, I. Anthropology froma pragmatic point of view. The Hague 1974.

Klein, D. C. Thehumiliation dynamic: An overview. "The J ournal of Primary Prevention", 12, 1991, pp. 93-121.

Kleinginna, P.R., Kleinginna, A.M. A Categorized List of Emotion Definitions with Suggestions for a Consensual Definition. "Motivation and Emotion", 1981. Vol. 5, No 4, pp. 345-379.

Morris, C. G. Psychology: An introduction (3rd ed.). Englewood Cliffs, New J ersey 1979.

Okasha, A. Mental Health in Egypt “The Israel J ournal of Psychiatry and Related Sciences". 2005. 42 (2), pp.116-25.

Panksepp, J . A critical role for 'affective neuroscience' in resolving what is basic about basic emotions. “Psychology Review”, 1992. Vol. 99, No. 3, pp. 554-560.

Panksepp, J . Affective neuroscience - the foundation of human and animal emotions. Oxford 2005.

Peters, R. S. The education of the emotions. In M. B. Arnold (Ed.), Fedings and emotions: Loyola Symposium New Y ork 1970.

Plutchik, R. The emotions: Facts, theories, and a new model. New Y ork 1962. 
Plutchik, R. Emotion: .A psychoevolutionary synthesis. New York 1980.

Plutchik, R. The Emotions, Lanham1991.

Potter, J., Edwards, D. Discursive social psychology. In: W. P. Robinson and H. Giles. (eds), The New Handbook of Language and Social Psychology London 2001, pp. 103-118.

Potter, J. Discourse analysis and discursive psychology. In P.M. Camic, J.E. Rhodes and L. Y ardley (Eds). Qualitative research in psychology: Expanding perspectives in methodology and design. Washington 2003, pp. 73-94.

Potter, J., Wetherell, M. Discourse and Social Psychology: Beyond Attitudes and Behaviour. London 1987.

Staats, S. R., Stassen, M. A. Hope: An affective cognition. "Social Indicators Re search", 1985. 17, pp. 235-242.

Schacter, D.L., Gilbert, D.T., Wegner, D.M. Psychology. New York 2012.

Sheehy, N., Chapman, A. J., Conroy, W. A. Biographical Dictionary of Psychology. London - New York 2002.

Smith, T.W. The Book of Human Emotions. An Encyclopedia of Feding from Anger to Wanderlust. Little 2015.

Thomas, A., Chess, S. Temperament and development. New York 1977.

\section{Research data}

1. An Inside Look at Family Mediation, URL:

https://www.youtube.com/watch?v=p89vyvgWQ9s. [17.09.2019].

2. Resolution through Mediation, URL: https://www.youtubecom/watch?v=XTbjeHwX-w [17.09.2019].

3. Victim-Offender Mediation, URL: https://www.youtubecom/watch?v=7d] kxJ wO3AU [17.09.2019].

4. Considering mediation? What you need to know? URL: https://www.youtube.com/watch?v=RkTz_9AM3Mo [17.09.2019]..

5. Family Mediation in Action, URL: https://www.youtubecom/watch?v=21BVczueiOl [17.09.2019].. 